
$\mathrm{LiNi}_{0.5} \mathrm{Mn}_{1.5} \mathrm{O}_{4}$ spinels prepared by wet chemistry

Received: 5 April 2006 / Accepted: 28 May 2006 / Published online: 10 June 2006

C) Springer-Verlag 2006

\begin{abstract}
We present the synthesis, characterization, and electrode behavior of $\mathrm{LiNi}_{0.5} \mathrm{Mn}_{1.5} \mathrm{O}_{4}$ spinels prepared by the wet-chemical method via citrate precursors. The phase evolution was studied as a function of nickel substitution and upon intercalation and deintercalation of $\mathrm{Li}$ ions. Characterization methods include X-ray diffraction, SEM, Raman, Fourier transform infrared, superconducting quantum interference device, and electron spin resonance. The crystal chemistry of $\mathrm{LiNi}_{0.5} \mathrm{Mn}_{1.5} \mathrm{O}_{4}$ appears to be strongly dependent on the growth conditions. Both normal-like cubic spinel $[F d 3 m$ space group (SG)] and ordered spinel $\left(P 4_{1} 32 \mathrm{SG}\right)$ structures have been formed using different synthesis routes. Raman scattering and infrared features indicate that the vibrational mode frequencies and relative intensities of the bands are sensitive to the covalency of the (Ni, Mn)-O bonds. Scanning electron microscopy (SEM) micrographs show that the particle size of the $\mathrm{LiNi}_{0.5} \mathrm{Mn}_{1.5} \mathrm{O}_{4}$ powders ranges in the submicronic domain with a narrow grain-size distribution. The substitution of
\end{abstract}

\footnotetext{
N. Amdouni · F. Gendron · C. M. Julien $(\bowtie)$

Institut des Nano-Sciences de Paris,

CNRS-UMR7588, campus Boucicaut,

Université Pierre et Marie Curie,

140 rue de Lourmel,

75015 Paris, France

e-mail: christian.julien@insp.jussieu.fr
}

K. Zaghib

Institut de Recherches d'Hydro-Québec,

1800 Boul. Lionel-Boulet,

Varennes, Québec, J3X 1S1, Canada

\section{A. Mauger}

Département MIPPU,

CNRS, campus Boucicaut,

140 rue de Lourmel,

75015 Paris, France

\section{Present address:}

N. Amdouni

Laboratoire de Chimie des Matériaux,

Faculté des Sciences de Tunis,

Université de Tunis El Manar, Campus Universitaire,

2092 El Manar II, Tunisia the $3 \mathrm{~d}^{8}$ metal for $\mathrm{Mn}$ in $\mathrm{LiNi}_{0.5} \mathrm{Mn}_{1.5} \mathrm{O}_{4}$ oxides is beneficial for its charge-discharge cycling performance. For a cut-off voltage of 3.5-4.9 V, the electrochemical capacity of the $\mathrm{Li} / / \mathrm{LiNi}_{0.5} \mathrm{Mn}_{1.5} \mathrm{O}_{4}$ cell is ca. $133 \mathrm{mAh} / \mathrm{g}$ during the first discharge. Differences and similarities between $\mathrm{LiMn}_{2} \mathrm{O}_{4}$ and $\mathrm{LiNi}_{0.5} \mathrm{Mn}_{1.5} \mathrm{O}_{4}$ oxides are discussed.

Keywords Spinel - Lithium batteries - Nickel doping · Wet synthesis $\cdot$ Local structure

\section{Introduction}

The cyclability of $\mathrm{Li}^{+}$ion transfer in Li-ion rechargeable batteries depends mainly on the dimensional stability of the host material during insertion and deinsertion of $\mathrm{Li}^{+}[1]$. Recently, it was found that redox reactions of nonstoichiometric or doped $\mathrm{Li}_{y} \mathrm{Mn}_{2-y} \mathrm{O}_{4}(M=\mathrm{Li}, \mathrm{Co}, \mathrm{Cr}, \mathrm{Ni}, \mathrm{Al}$, etc.) spinels are much better than that of the pure $\mathrm{LiMn}_{2} \mathrm{O}_{4}$ ceramics, which exhibit a slight capacity fading [2]. These materials have been investigated to improve the cycling performance of $\mathrm{LiMn}_{2} \mathrm{O}_{4}$, showing a tetragonal distortion induced by the excess of $\mathrm{Mn}^{3+} \mathrm{Jahn}-$ Teller ions in deeply discharged electrode. However, all the reported doping methods have led to a decreased specific charge compared to the undoped $\mathrm{LiMn}_{2} \mathrm{O}_{4}$ materials so far. The search of high-voltage material electrodes has been focused on two categories: the inverse spinels, e.g., $\mathrm{Li} M \mathrm{VO}_{4}$, and the normal spinels, $\mathrm{Li}_{y} \mathrm{Mn}_{2-y} \mathrm{O}_{4}$.

Recent investigations have shown that, among the Ni-substituted $\mathrm{LiMn}_{2} \mathrm{O}_{4}$ spinels, the composition $\mathrm{LiNi}_{0.5} \mathrm{Mn}_{1.5} \mathrm{O}_{4}$ possesses specific electrochemical characteristics such as a high capacity of $130-140 \mathrm{mAh} / \mathrm{g}$ associated with a high-voltage plateau in the 5-V range [325]. Gao et al. [3] investigated the origin of the voltage profile for $\mathrm{LiNi}_{y} \mathrm{Mn}_{2-y} \mathrm{O}_{4}$. For the same system, Zhong et al. [4] showed the effects of the synthesis route (sol-gel vs solid state) on some structural and electrochemical properties. The almost flat voltage profile was confirmed by Ohzuku et al. [13]. All these works only reported on structural and electrochemical information, and few of them 
concerned the physical properties of the $\mathrm{LiNi}_{0.5} \mathrm{Mn}_{1.5} \mathrm{O}_{4}$ material. Blasse [26] showed in 1966 that $\mathrm{LiNi}_{0.5} \mathrm{Mn}_{1.5} \mathrm{O}_{4}$ is a ferrimagnetic spinel material with $\mathrm{Ni}^{2+}$ and $\mathrm{Mn}^{4+}$ on octahedral sites and $\mathrm{Li}$ on tetrahedral sites. In their studies of $\mathrm{LiNi}_{0.5} \mathrm{Mn}_{1.5} \mathrm{O}_{4}$ by neutron diffraction and IR spectroscopy, Gryffroy and Vandenberghe [27] showed the structure in terms of the 1:3 cation-ordering at $B$ sites of the $A\left[B_{2}\right] \mathrm{O}_{4}$ spinel structure, i.e., $16 d$ sites in $F d 3 m$, with a cubic symmetry $P_{3} 32$ space group (SG). A schematic representation of the structure of the normal spinel and the 1:3 ordered spinel is shown in Fig. 1. Recently, the formation of the ordered spinel has been confirmed by combining X-ray diffraction (XRD) and Fourier transform infrared (FTIR) measurements [6, 15].

Several methods have been used to synthesize $\mathrm{LiNi}_{0.5} \mathrm{Mn}_{1.5} \mathrm{O}_{4}$. These methods are solid-state reaction [7], sol-gel method [8,9], molten salt technique [10], emulsion drying method [11], composite carbonate process [12], coprecipitation method [13], and melt-impregnation synthesis [14]. Thin-films of $\mathrm{LiNi}_{0.5} \mathrm{Mn}_{1.5} \mathrm{O}_{4}$ have been prepared by electrostatic spray deposition [15]. Results have shown that $\mathrm{LiNi}_{0.5} \mathrm{Mn}_{1.5} \mathrm{O}_{4}$ materials were obtained with different properties. In fact, the key parameter in electrochemical capacity fading could be rather the oxide morphology (grain size and/or specific surface area), as shown by the remarkable improvement reported on sol-gel $\mathrm{LiNi}_{0.5} \mathrm{Mn}_{1.5} \mathrm{O}_{4}$ [25].

The aim of this communication is the growth and characterization of the $\mathrm{LiNi}_{0.5} \mathrm{Mn}_{1.5} \mathrm{O}_{4}$ materials prepared by wet chemistry. We use two different techniques, i.e., the sol-gel method assisted by citric acid and the combustion technique assisted by glycine. The $\mathrm{LiNi}_{0.5} \mathrm{Mn}_{1.5} \mathrm{O}_{4}$ system crystallizes, in peculiar synthesis conditions, as either an ordered- or a normal-spinel phase. The synthesis process has been studied by thermogravimetry (TG) and differential thermal analysis (DTA). The long-range structure and local atomic environment are investigated by XRD, Raman scattering (RS), and FTIR spectroscopy. Electronic properties are investigated by electron spin resonance (ESR) and superconducting quantum interference device (SQUID) magnetometry, which also probe the local structure. Finally, we also report the difference in electrochemical properties of the two structural types of $\mathrm{LiNi}_{0.5} \mathrm{Mn}_{1.5} \mathrm{O}_{4}$ materials.

\section{Experimental description}

\section{Synthesis}

To compare the effect of the synthesis method, two $\mathrm{LiNi}_{0.5} \mathrm{Mn}_{1.5} \mathrm{O}_{4}$ samples were prepared by sol-gel synthesis and combustion process, both using carboxylic acid as chelating agent. The choice of these wet-chemical techniques has been guided by the remarks of Zhong et al. [4]. The sol-gel and combustion synthesis occurred from metal acetates via inorganic polymerization reactions in solution according to methods reported in our previous works $[28,29]$. Compared with the conventional solid-state reaction, it is believed that these techniques offer many advantages such as lower temperature processing and better control of material morphology.

The procedure for the sol-gel synthesis has been detailed elsewhere [28]. Reagent grade $\mathrm{Li}\left(\mathrm{CH}_{3} \mathrm{COO}\right) \cdot 2 \mathrm{H}_{2} \mathrm{O}$, $\mathrm{Ni}\left(\mathrm{CH}_{3} \mathrm{COO}\right)_{2} \cdot 4 \mathrm{H}_{2} \mathrm{O}$, and $\mathrm{Mn}\left(\mathrm{CH}_{3} \mathrm{COO}\right)_{2} \cdot 4 \mathrm{H}_{2} \mathrm{O}$ were selected as raw materials. The powder samples of $\mathrm{LiNi}_{0.5} \mathrm{Mn}_{1.5} \mathrm{O}_{4}$ were prepared using stoichiometric amounts of $\mathrm{Li}\left(\mathrm{CH}_{3} \mathrm{COO}\right) \cdot 2 \mathrm{H}_{2} \mathrm{O}, \mathrm{Ni}\left(\mathrm{CH}_{3} \mathrm{COO}\right)_{2} \cdot 4 \mathrm{H}_{2} \mathrm{O}$, and $\mathrm{Mn}\left(\mathrm{CH}_{3} \mathrm{COO}\right)_{2} \cdot 4 \mathrm{H}_{2} \mathrm{O}$ acetate dissolved in distilled water and added to a continuously stirred aqueous solution, and then evaporated at $80{ }^{\circ} \mathrm{C}$ until a transparent gel was obtained. The resulting slurries were heated at $400{ }^{\circ} \mathrm{C}$ for a few hours to get the product of the composition $\mathrm{LiNi}_{0.5} \mathrm{Mn}_{1.5} \mathrm{O}_{4}$. Accordingly, the powder mass was slightly ground and then fired at $680{ }^{\circ} \mathrm{C}$ in air for $5 \mathrm{~h}$ to improve the crystallinity of the $\mathrm{LiNi}_{0.5} \mathrm{Mn}_{1.5} \mathrm{O}_{4}$ final product.

The combustion method (glycine-nitrate pyrolysis) has been reported by Chitra et al. and Julien et al. [29, 30]. In this technique, stoichiometric amounts of Li-, Ni-, and $\mathrm{Mn}$ nitrate salts were dissolved in triple-distilled water with a small proportion of ethanol and aqueous solution of glycine (amino-acetic acid, $\mathrm{NH}_{2} \mathrm{CH}_{2} \mathrm{COOH}$ ). In this case, care was exercised in adjusting the concentration of the complexing agent; the $\mathrm{pH}$ of the solution ranged between 5 and 6 .
Fig. 1 Schematic representation of the structure of $\mathrm{AB}_{2} \mathrm{O}_{4}$ spinel lattices. a The smallest (primitive) cubic unit cell of normal spinel $(F d 3 m)$ and $\mathbf{b}$ the unit cell of the $1: 3$ ordered spinel $\left(P 4_{1} 32\right)$. The structure is composed of alternating octants of $\mathrm{AO}_{4}$ tetrahedra and $\mathrm{B}_{4} \mathrm{O}_{4}$ cubes to build the face-centered cubic unit cell
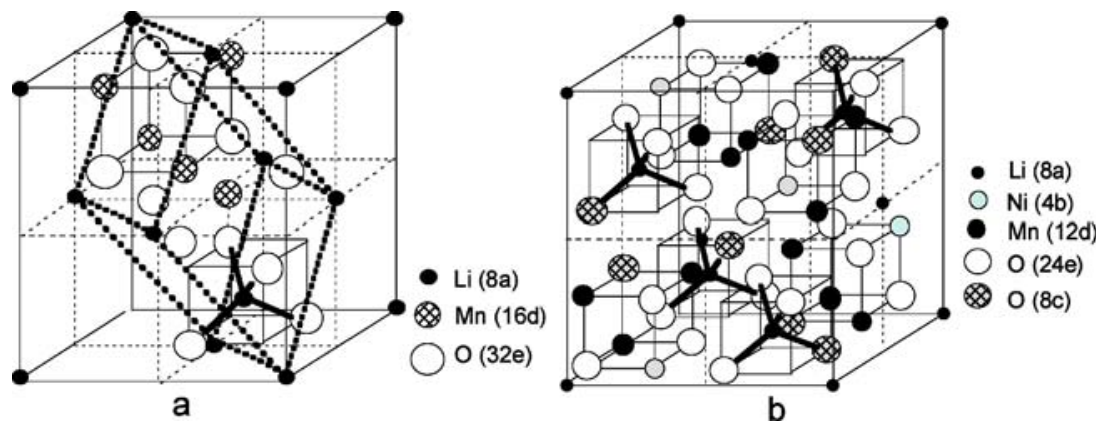
Table 1 Elemental analyses of the reaction products and structural data of $\mathrm{LiNi}_{0.5} \mathrm{Mn}_{1.5} \mathrm{O}_{4}$ samples

\begin{tabular}{lllllll}
\hline Sample & $\mathrm{Li}($ wt.\%) & $\mathrm{Ni}($ wt.\%) & $\mathrm{Mn}($ wt.\%) & Composition & $\mathrm{SG}$ & $a(\AA)$ \\
\hline Sol-gel & 3.81 & 15.80 & 45.35 & $\mathrm{LiNi}_{0.49} \mathrm{Mn}_{1.49} \mathrm{O}_{4}$ & $F d 3 m$ & $8.182(7)$ \\
Pyrolysis & 3.83 & 15.70 & 45.15 & $\mathrm{LiNi}_{0.49} \mathrm{Mn}_{1.5} \mathrm{O}_{4}$ & $P 4{ }_{1} 32$ & $8.168(5)$ \\
Theoretical & 3.80 & 16.07 & 45.11 & $\mathrm{LiNi}_{0.5} \mathrm{Mn}_{1.5} \mathrm{O}_{4}$ & - & - \\
\hline
\end{tabular}

\section{Apparatus}

TG-DTA analysis of the precursors was obtained using a thermogravimetric analyzer (model Netzsch STA 409) at a heating rate $0.1{ }^{\circ} \mathrm{C} / \mathrm{s}$ under oxygen flow. Elemental analysis of the final products was determined using an induced coupled plasma (ICP) mass spectrometer (model VG Plasma Quad II-S) by dissolving the given powder samples in $\mathrm{HCl}$. The phase identification was carried out by XRD using a Philips X'Pert PRO Materials Research Diffractometer (PW3050) diffractometer equipped with a $\mathrm{Cu}$ anticathode $\left(\mathrm{CuK}_{\alpha}\right.$ radiation $\left.\lambda=1.54056 \AA\right)$ at room temperature. The measurements were recorded under Bragg-Brentano geometry at $2 \theta$ with step $0.05^{\circ}$ in the range $10-80^{\circ}$. The XRD data were analyzed by the Rietveld profile refinements using the Fullprof program. The particle morphology of the $\mathrm{LiNi}_{0.5} \mathrm{Mn}_{1.5} \mathrm{O}_{4}$ powders was examined with a scanning electron microscope (SEM, Philips XL30). Magnetic measurements were performed in a SQUID magnetometer (Quantum Design MPMS-5S). Zero-field-cooled and field-cooled magnetic susceptibility data were obtained in a field at $1 \mathrm{~T}$ in the temperature range $4 \leq T \leq 300 \mathrm{~K}$.

The FTIR absorption spectra were recorded with a Fourier transform interferometer (model Bruker IFS113v) in the wavenumber range $120-1,200 \mathrm{~cm}^{-1}$ at a spectral resolution $2 \mathrm{~cm}^{-1}$. Samples were ground to fine powders and dispersed into CsI pellet. RS spectra were collected with a Raman-laser spectrometer (Jobin-Yvon model U1000) equipped with holographic grating double-monochromator coupled with a spatial filter. Powders were press-compacted into pellet to form a mirror-like surface illuminated with the 514.5-nm emission from an Ar-ion laser (model Spectra-Physics 2020). Each RS spectrum was the average of 10 scans collected at a spectral resolution of $1 \mathrm{~cm}^{-1}$. The curve fitting is based on the original algorithm of nonlinear peak fitting described by Marquardt, and known as the Levenberg-Marquardt method [31], by using the GRAM/386 software from Galactic Industries. The fitting calculations were done assuming a linear baseline for the spectra and that all the Raman lines introduced in the fit had a mixed GaussLorentz line shape [32].

The electrochemical properties of the product were tested at room temperature in cells with metallic lithium as anode electrode. Measurements were carried out following the experimental procedure previously described [33] using Teflon laboratory-cell hardware and the Mac-Pile system. Quasi open-circuit voltage curves were recorded using a current pulse of $0.1 \mathrm{~mA} / \mathrm{cm}^{2}$ applied for $1 \mathrm{~h}$ followed by a relaxation period of $0.5-1.0 \mathrm{~h}$, which allows the recording of the transient voltage for the determination of chemical diffusion coefficients of $\mathrm{Li}^{+}$ions in the $\mathrm{LiNi}_{0.5} \mathrm{Mn}_{1.5} \mathrm{O}_{4}$ lattice.

\section{Results and discussion}

Synthesis, structure, and morphology

ICP measurements were carried out on $\mathrm{LiNi}_{0.5} \mathrm{Mn}_{1.5} \mathrm{O}_{4}$ oxides for determination of their elemental analysis. As shown in Table 1, both samples have a composition near the ideal one. These results prove that (1) the wet-chemical
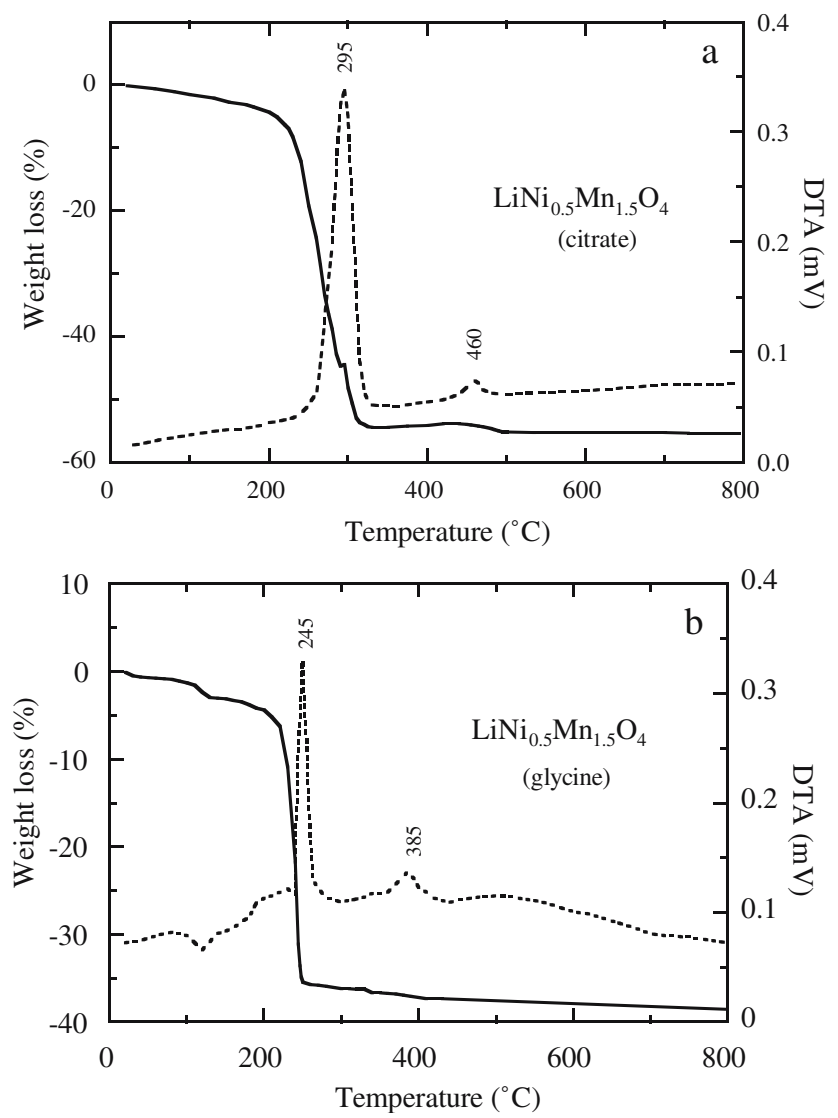

Fig. 2 TG and DTA of $\mathrm{LiNi}_{0.5} \mathrm{Mn}_{1.5} \mathrm{O}_{4}$ grown by a sol-gel method via citric acid and $\mathbf{b}$ combustion method via glycine 
synthesis assisted by glycine provides better stoichiometric samples than succinic acid and (2) no significant loss of lithium oxide has occurred during the thermal treatment.

Figure 2a,b shows the TG-DTA curves of $\mathrm{LiNi}_{0.5} \mathrm{Mn}_{1.5} \mathrm{O}_{4}$ powders grown by the sol-gel method via citric acid and the pyrolysis synthesis via glycine, respectively. The thermal analyses of materials grown by wet-chemical methods are characterized by three steps: (1) the removal of water up to $200{ }^{\circ} \mathrm{C},(2)$ a strong exothermic reaction in the range $240-300^{\circ} \mathrm{C}$, and (3) the region of crystallization of the final product $\mathrm{LiNi}_{0.5} \mathrm{Mn}_{1.5} \mathrm{O}_{4}$ above $400{ }^{\circ} \mathrm{C}$.

In both methods, the strong exothermic peak appears at 295 (sol-gel) and at $245{ }^{\circ} \mathrm{C}$ (pyrolysis) after the departure of the remaining water from the xerogel. The exothermic heat generated from the decomposition of acetate-ions xerogel and the combustion of the carboxylic acid, i.e., citric acid or glycine, is predicted to be utilized as the lattice energy required for the formation of $\mathrm{LiNi}_{0.5} \mathrm{Mn}_{1.5} \mathrm{O}_{4}$ phase. More than half of the weight loss occurs during this stage because of a violent oxidation-decomposition reaction. It appeared that citric acid and glycine acted as a fuel in the calcination of the gel precursor, accelerating the decomposition of acetate ions. The gel precursor was self-burning once ignited because the decomposed acetate ions acted as an oxidizer. The crystallization starts below $400{ }^{\circ} \mathrm{C}$; thus, a well-crystallized and pure $\mathrm{LiNi}_{0.5} \mathrm{Mn}_{1.5} \mathrm{O}_{4}$ phase was obtained at $680{ }^{\circ} \mathrm{C}$. While the calcination process at this stage was very complicated, it could be presumed that the last weak exothermic at ca. $460{ }^{\circ} \mathrm{C}$ in the DTA curve corresponds to the crystallization of the $\mathrm{LiNi}_{0.5} \mathrm{Mn}_{1.5} \mathrm{O}_{4}$ phase. During this process the mass precursor darkened progressively as a result of oxidation.

Figure 3 presents the XRD patterns of $\mathrm{LiNi}_{0.5} \mathrm{Mn}_{1.5} \mathrm{O}_{4}$ phases grown by the citrate and the glycine route. The diagram of the normal spinel $\mathrm{LiMn}_{2} \mathrm{O}_{4}(F d 3 m \mathrm{SG})$ is shown for comparison. The $\mathrm{LiNi}_{0.5} \mathrm{Mn}_{1.5} \mathrm{O}_{4}$ powders exhibit phase-pure cubic spinel without impurities as far as XRD is concerned. When products are calcined above $800{ }^{\circ} \mathrm{C}$, the materials decompose with the occurrence of impurities such as $\mathrm{NiO}$ and $\mathrm{Li}_{z} \mathrm{Ni}_{1-z} \mathrm{O}$, which could give rise to XRD lines at $2 \theta=37.5,43.8$, and $63.8^{\circ}$. Here, we confirm that $\mathrm{NiO}$ impurities can be removed by a recalcination process. The diffraction patterns of $\mathrm{LiNi}_{0.5} \mathrm{Mn}_{1.5} \mathrm{O}_{4}$ grown by the sol-gel method can be indexed by comparing those of $\mathrm{LiMn}_{2} \mathrm{O}_{4}$ in the cubic system with $\mathrm{Fd} 3 \mathrm{~m}$ symmetry. The results of structure refinements show a decrease of the lattice parameter which falls from $a=8.243 \AA$ for $\mathrm{LiMn}_{2} \mathrm{O}_{4}$ to $a=8.182 \AA$ for $\mathrm{LiNi}_{0.5} \mathrm{Mn}_{1.5} \mathrm{O}_{4}$ sol-gel phase.

The diffraction patterns of $\mathrm{LiNi}_{0.5} \mathrm{Mn}_{1.5} \mathrm{O}_{4}$ grown by the pyrolysis method have been indexed in the cubic $P 4_{1} 32$ symmetry rather than the cubic $F d 3 m$ SG due to additional weak lines located at $2 \theta=15.3,39.7,45.7$, and $57.5^{\circ}$, which are absent from that of the $F d 3 m$ structure, and the lowering symmetry observed in the resonance spectroscopy (Raman and FTIR), which could not be detected by XRD due to the small contrast of XRD patterns. Similar results

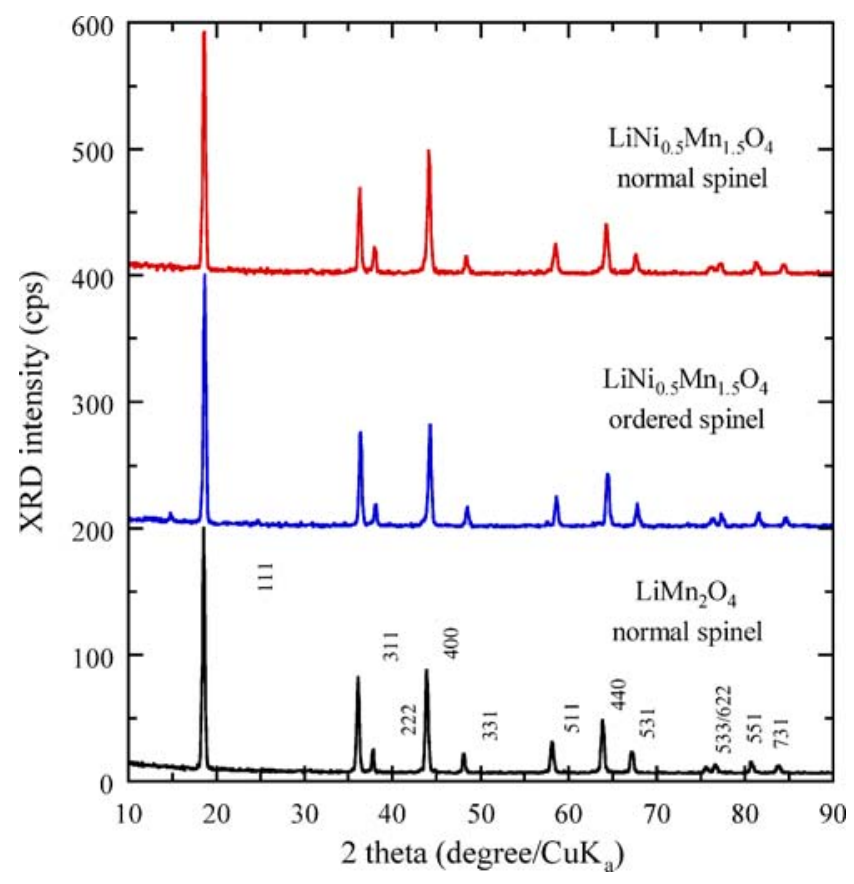

Fig. $3 \mathrm{XRD}$ patterns of $\mathrm{LiNi}_{0.5} \mathrm{Mn}_{1.5} \mathrm{O}_{4}$ phases grown by wetchemistry. The normal-spinel structure $(F d 3 m$ SG) was synthesized by sol-gel method, while the ordered-spinel phase $\left(P 4_{1} 32 \mathrm{SG}\right)$ was grown by pyrolysis route. The patterns of the normal spinel $\mathrm{LiMn}_{2} \mathrm{O}_{4}(F d 3 m \mathrm{SG})$ are shown by comparison

have been reported for $\mathrm{LiNi}_{0.5} \mathrm{Mn}_{1.5} \mathrm{O}_{4}$ and $\mathrm{LiMg}_{0.5} \mathrm{Mn}_{1.5} \mathrm{O}_{4}$ $[16,34]$. Therefore, the primitive unit cell in the cubic system with the $P 4_{1} 32$ (or $P 4_{2} 32$ ) SG results in the superstructure from the 1:3 cation ordering. The cubic cell parameter $a=8.1685 \AA$ is in agreement with previously reported values which describe an octahedrally ordered spinel structure [16-19]. We assume similar distribution of the atoms, namely, $\mathrm{Li}$ on $8 c$, Ni on $4 b, \mathrm{Mn}$ on $12 d$, O(1) on $24 e$, and $\mathrm{O}(2)$ on $8 c$ Wyckoff positions. The SG $P 4_{1} 32$ allows placing the larger $\mathrm{Ni}^{2+}$ ions (ionic radius $0.69 \AA$ ) in the bigger $4 b$ site instead of the $16 d$ site of normal spinel structure. The smaller unit cell dimension is primarily due to the change in the $\mathrm{Mn}$ oxidation state. Despite the replacement of a fraction of $\mathrm{Mn}$ ions by bigger $\mathrm{Ni}^{2+}$ ions, the $\mathrm{Mn}$ valence change effect prevails [5]. Recently, Strobel et al. [6] suggested that the occurrence of cation ordering corresponds to the largest valence difference $\Delta \mathrm{Z}$ $(M n-M) \geq 2$. The net result is thus a significant optimization of space occupation, leading to a reduced unit cell volume.

In general, several factors can contribute to the broadening of peaks in X-ray diffraction [35]. For example, instrumental factors related to the resolution and the incident X-ray wavelength, as well as sample factors such as crystallite size and nonuniform microstrain, can cause line broadening. In the case of instrumental broadening, line width will vary smoothly with $2 \theta$ or $d$ spacing. On the other hand, line broadening that originates from sample characteristics will have a different relationship. By combining the Scherrer's equation for crystallite size and 
Table 2 Structural parameters of $\mathrm{LiMn}_{2} \mathrm{O}_{4}$ and $\mathrm{LiNi}_{0.5} \mathrm{Mn}_{1.5} \mathrm{O}_{4}$ spinels prepared by wet-chemical method from the citrate precursor route

\begin{tabular}{llll}
\hline Sample & $a(\AA)$ & $L(\mathrm{~nm})$ & $<\mathrm{e}^{2}>\times 10^{6}$ \\
\hline $\mathrm{LiMn}_{2} \mathrm{O}_{4}$ & $8.224(0)$ & 320 & 1.53 \\
$\mathrm{LiNi}_{0.5} \mathrm{Mn}_{1.5} \mathrm{O}_{4}$ & $8.182(7)$ & 255 & 1.67 \\
\hline
\end{tabular}

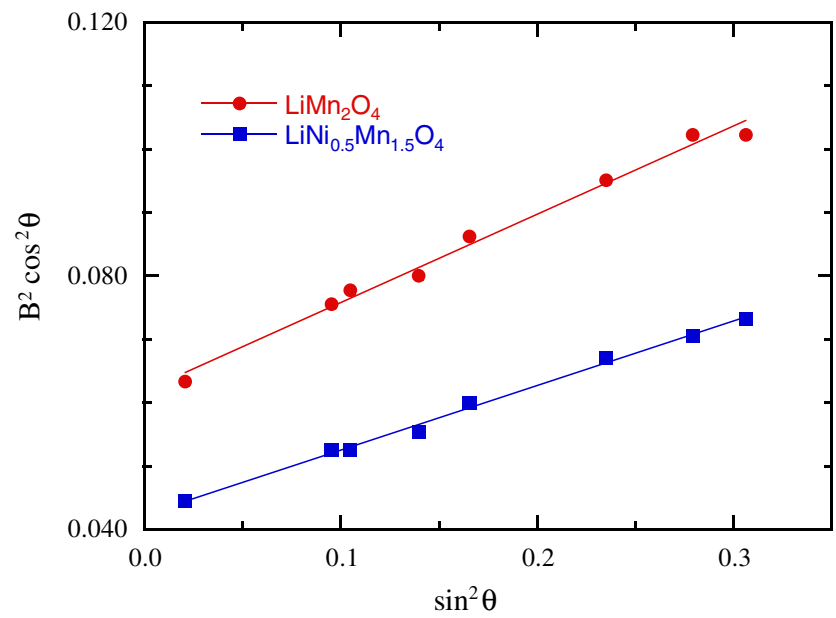

Fig. 4 Plots of $B^{2} \cos ^{2} \theta$ vs $\sin ^{2} \theta$ for XRD patterns of $\mathrm{LiMn}_{2} \mathrm{O}_{4}$ and $\mathrm{LiNi}_{0.5} \mathrm{Mn}_{1.5} \mathrm{O}_{4}$ normal spinel phases grown by wet-chemical method. The Bragg lines were indexed using the cubic Fd3m SG

the Bragg's law for diffraction, crystallite size and microstrain components are estimated by using the following equation:

$B^{2} \cos ^{2} \theta=16\left\langle e^{2}\right\rangle \sin ^{2} \theta+\frac{K^{2} \lambda^{2}}{L^{2}}$,

where $B$ is the full-width at half-maximum after correction of instrumental broadening for finely powdered silicon powder, $\theta$ is the diffraction angle, $\left\langle e^{2}\right\rangle$ denotes local strains (defined as $\Delta d / d$ being the interplanar spacing), $L$ is the crystallite size, and $K$ is a near-unity constant related to crystallite shape. Plots of eight reflections for the $\mathrm{LiNi}_{0.5} \mathrm{Mn}_{1.5} \mathrm{O}_{4}$ and $\mathrm{LiMn}_{2} \mathrm{O}_{4}$ are presented in Fig. 4. The slope, $16<e^{2}>$, and intercept, $K^{2} \lambda^{2} / L^{2}$, were used to estimate the distortion and size parameters. Apparently, the integral breadth of Bragg lines of the doped spinel is slightly greater than those of pure samples, which suggests a smaller grain size and a higher microstrain content in $\mathrm{LiNi}_{0.5} \mathrm{Mn}_{1.5} \mathrm{O}_{4}$ (Table 2).

The shape and morphology of the particles in spinel samples obtained by different methods were followed by SEM. Figure 5 shows the SEM images of the products calcined at $680{ }^{\circ} \mathrm{C}$. It is shown that the $\mathrm{LiNi}_{0.5} \mathrm{Mn}_{1.5} \mathrm{O}_{4}$ powders consist of well-developed particles. The average particle size is estimated to be $200-280 \mathrm{~nm}$ for materials prepared by the sol-gel technique and $300-400 \mathrm{~nm}$ for materials prepared by the pyrolysis method. Moreover, the $\mathrm{LiNi}_{0.5} \mathrm{Mn}_{1.5} \mathrm{O}_{4}$ powders exhibit a uniform particle size distribution.

\section{Raman and FTIR studies}

Structural properties of $\mathrm{LiNi}_{0.5} \mathrm{Mn}_{1.5} \mathrm{O}_{4}$ phases grown by wet-chemical route with replacement of exactly $1 / 4 \mathrm{~B}$ site (octahedral cations) were also investigated by vibrational spectroscopy. Because Raman and FTIR are local probes sensitive to the crystal symmetry, they are useful tools when poor chemical contrast of XRD prevents the determination of the structure (amorphous structure, cation ordering, etc.). Figure 6 shows the RS spectra of $\mathrm{LiNi}_{0.5} \mathrm{Mn}_{1.5} \mathrm{O}_{4}$ powders displaying obvious differences to their $\mathrm{LiMn}_{2} \mathrm{O}_{4}$ counterparts. The RS spectrum of $\mathrm{LiMn}_{2} \mathrm{O}_{4}$ consists of a series of broad bands between 300 and $700 \mathrm{~cm}^{-1}$. The peaks at 625 (symmetric Mn-O stretching vibration of $\mathrm{MnO}_{6}$ groups), $580,483,426$, and $362 \mathrm{~cm}^{-1}$ are assigned to $A_{1 g}, F_{2 g}{ }^{(3)}, F_{2 g}{ }^{(2)}, E_{g}$, and $F_{2 g}{ }^{(1)}$ modes, respectively, as predicted by group theory for a cubic compound [36].

The introduction of $\mathrm{Ni}^{2+}$ ions in the spinel lattice $(F d 3 m$ SG) has modified the Raman spectra in a complicated manner. The following observations can be made: (1) The $625-\mathrm{cm}^{-1}$ band that is associated with the symmetric Mn-O stretching vibration of $\mathrm{MnO}_{6}$ octahedra shifts slightly to $636 \mathrm{~cm}^{-1}$. (2) New features at 395 and $496 \mathrm{~cm}^{-1}$ became strong, and thus, can be unequivocally assigned to the $\mathrm{Ni}^{2+}-\mathrm{O}$ stretching mode in the structure [37]. (3) The $F_{2 g}{ }^{(3)}$ splits in two components at 582 and $605 \mathrm{~cm}^{-1}$. The frequency shift of stretching vibration is attributed to (1) the increase of the average valence state of Mn ions and (2)
Fig. 5 SEM images of $\mathrm{LiNi}_{0.5} \mathrm{Mn}_{1.5} \mathrm{O}_{4}$ phases grown by wet-chemical route via citrate precursors. a Normal spinel $(F d 3 m)$ and $\mathbf{b}$ ordered spinel $(P 4,32)$. We note the difference in magnification between the images
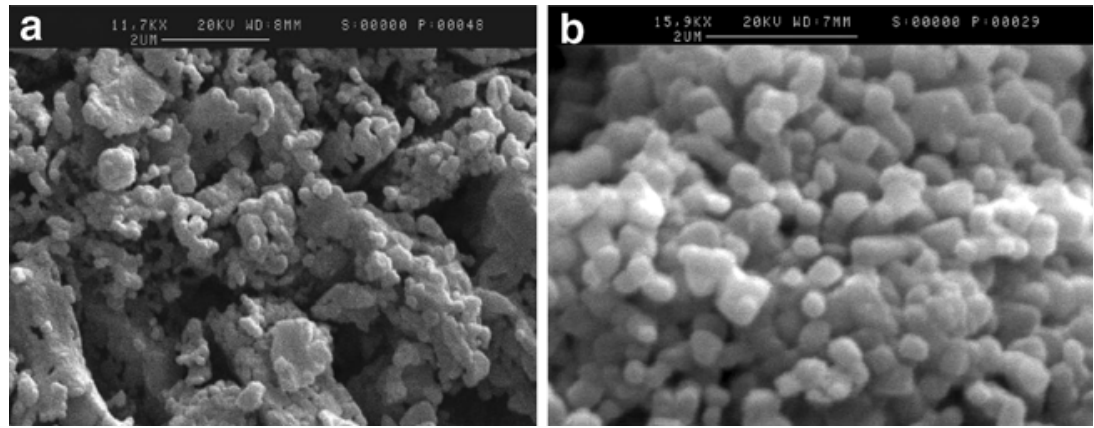


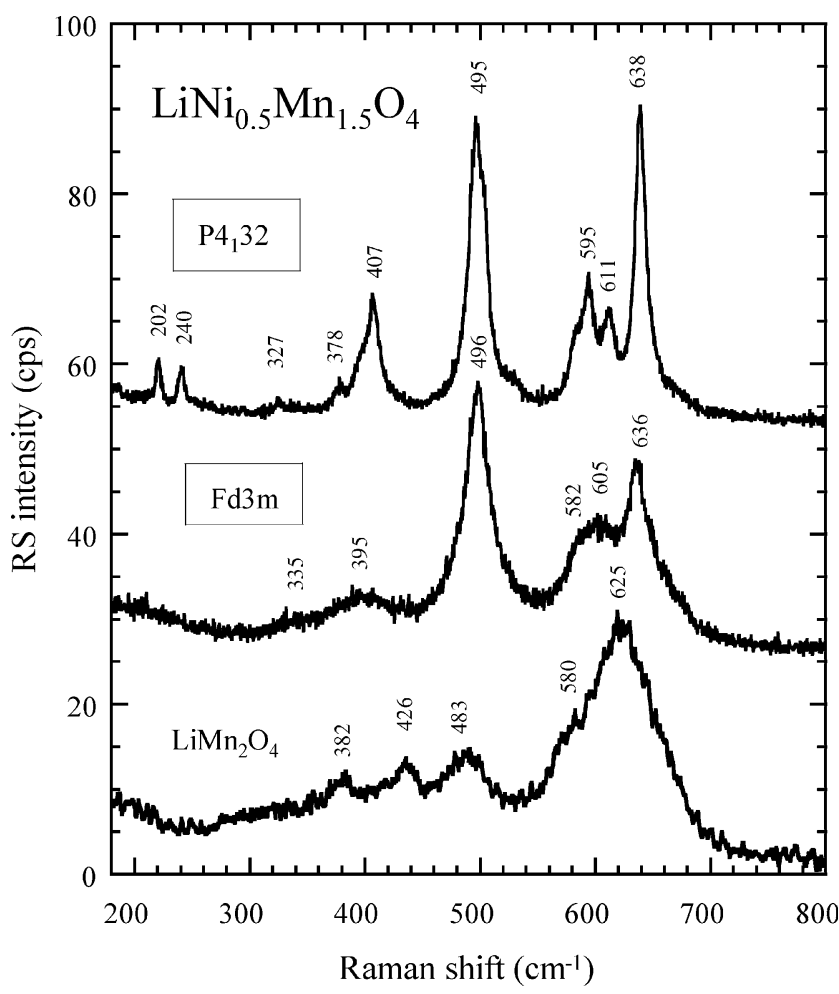

Fig. 6 RS spectra of $\mathrm{LiNi}_{0.5} \mathrm{Mn}_{1.5} \mathrm{O}_{4}$ powders compared with that of undoped normal-spinel $(F d 3 m)$. The $1: 3$ ordered phase $\left(P 4_{1} 32\right)$ gives a very different spectrum with much sharper lines resulting from the symmetry lowering. Spectra were fitted using the curve analysis based on a nonlinear peak fitting known as the LevenbergMarquardt method with Lorentzian line shape

the decrease in the unit cell volume. The small shift of the symmetric stretching vibration of $\mathrm{MnO}_{6}$ groups can be viewed as the shortness of $\mathrm{Mn}-\mathrm{O}$ bond lengths and polyhedral distortion occurring in $\mathrm{LiNi}_{0.5} \mathrm{Mn}_{1.5} \mathrm{O}_{4}$. The intensity of the shoulder located at $580 \mathrm{~cm}^{-1}$ is enhanced upon nickel substitution. This may be due to the change of the $\mathrm{Mn}^{3+} / \mathrm{Mn}^{4+}$ ratio vs $\mathrm{Ni}^{2+}$ in the material. The peak splitting between bands at 426 and $382 \mathrm{~cm}^{-1}$ is reduced between the bands at 407 and $378 \mathrm{~cm}^{-1}$ for $\mathrm{LiNi}_{0.5} \mathrm{Mn}_{1.5} \mathrm{O}_{4}$ due to the polyhedral distortion.
For well-controlled synthesis of $\mathrm{LiNi}_{0.5} \mathrm{Mn}_{1.5} \mathrm{O}_{4}$ grown by glycine-assisted pyrolysis method, RS spectrum indicates characteristic peaks originating from the formation of a superlattice. Analytical results are in accordance with the $P 4_{1} 32 \mathrm{SG}$ in which $\mathrm{Ni}^{2+}$ ions are located at the $4 a$ sites in the cubic-close packed oxygen array. Comparison with the disordered $\mathrm{LiNi}_{0.5} \mathrm{Mn}_{1.5} \mathrm{O}_{4}(F d 3 m \mathrm{SG}$ ) compound is made in Fig. 6. The main driving force for octahedral cation ordering is believed to be the charge difference between $\mathrm{Mn}$ and $\mathrm{Ni}$ atoms. For Ni substitution, the RS patterns show a dramatic increase in the number of active modes. Considering the symmetry correlation $O_{h}^{7} \rightarrow O^{7}$, the irreducible representations for normal spinel $\left(\Gamma_{\mathrm{NS}}\right)$ and for ordered spinel $\left(\Gamma_{\mathrm{OS}}\right)$ are given by (Table 3$)$.

$\Gamma_{N S}=A_{g}(R)+E_{g}(R)+3 F_{2 g}(R)+4 F_{1 u}(i r)$,

$\Gamma_{O S}=6 A_{1}(R)+14 E(R)+20 F_{1}(i r)+22 F_{2}(R)$.

It is obvious that the number of expected Raman-active modes $\left(6 A_{1}+14 E+22 F_{2}\right)$ is larger than for $\mathrm{LiMn}_{2} \mathrm{O}_{4}$ $\left(A_{g}+E_{g}+3 F_{2 g}\right)$. This prediction is well verified experimentally. The $\mathrm{LiNi}_{0.5} \mathrm{Mn}_{1.5} \mathrm{O}_{4}$ phase clearly shows an ordering of octahedral cations into $4 b$ and $12 d$ sites in SG $P 4_{1} 32\left(O^{7}\right.$ spectroscopic symmetry). Both contain small fractions of lithium on the $4 b$ site [6]. The sharpness of the Raman bands of the $\mathrm{LiMn}_{3 / 2} \mathrm{Ni}_{1 / 2} \mathrm{O}_{4}$ sample is the fingerprint of well separated $\mathrm{Ni}$ and $\mathrm{Mn}$ sites resulting from the symmetry lowering. As the integer valence distribution is $\left(\mathrm{Li}^{+}\right)\left(\mathrm{Ni}^{2+}\right)_{0.5}\left(\mathrm{Mn}^{4+}\right)_{1.5} \mathrm{O}_{4}$, the rather large broadness of the high-wavenumber band in normal spinel $\mathrm{LiMn}_{2} \mathrm{O}_{4}$ becomes a well-resolved triplet in ordered spinel lattice. This vibration is recorded at $500 \mathrm{~cm}^{-1}$ in the case of $\mathrm{NiO}$ [37].

Figure 7 shows the FTIR absorbance spectra of $\mathrm{LiNi}_{0.5} \mathrm{Mn}_{1.5} \mathrm{O}_{4}$ powders compared with that of undoped $\mathrm{LiMn}_{2} \mathrm{O}_{4}$ normal-spinel. Frequencies have been determined by fitting using a mixed Gauss-Lorentz line shape. The FTIR spectrum of $\mathrm{LiMn}_{2} \mathrm{O}_{4}$ consists of two broad bands $v_{1}$ and $v_{2}$ at ca. 615 and $513 \mathrm{~cm}^{-1}$. Weak shoulders are observed on the low-wavenumber side with the
Table 3 The irreducible representation of the vibrational active modes of the 1:3-ordered spinel phase in $O^{7}$ spectroscopic group

\begin{tabular}{llll}
\hline Atom & Wyckoff position & Point group & $\begin{array}{l}\text { Irreducible representation } \\
\text { (point group } \rightarrow O^{7} \text { correlation) }\end{array}$ \\
\hline $\mathrm{Li}$ & $8 c$ & $C_{3}$ & $A_{1}+A_{2}+2 E+3 F_{1}+3 F_{2}$ \\
$\mathrm{Mn}$ & $12 d$ & $C_{2}$ & $A_{1}+A_{2}+2 E+5 F_{1}+5 F_{2}$ \\
$\mathrm{Ni}$ & $4 b$ & $D_{3}$ & $A_{2}+2 E+3 F_{1}+3 F_{2}$ \\
$\mathrm{O} 1$ & $C_{3}$ & $A_{1}+A_{2}+2 E+3 F_{1}+3 F_{2}$ \\
$\mathrm{O} 2$ & $8 c$ & $3 A_{1}+3 A_{2}+6 E+9 F_{1}+9 F_{2}$ \\
Total & $24 e$ & \\
Acoustic & $6 A_{1}+7 A_{2}+14 E+23 F_{1}+22 F_{2}$ & \\
Inactive & $3 F_{1}$ & \\
Raman (42 modes) & $7 A_{2}$ & & \\
Infrared (20 modes) & $6 A_{1}+14 E+22 F_{2}$ & & \\
\hline
\end{tabular}




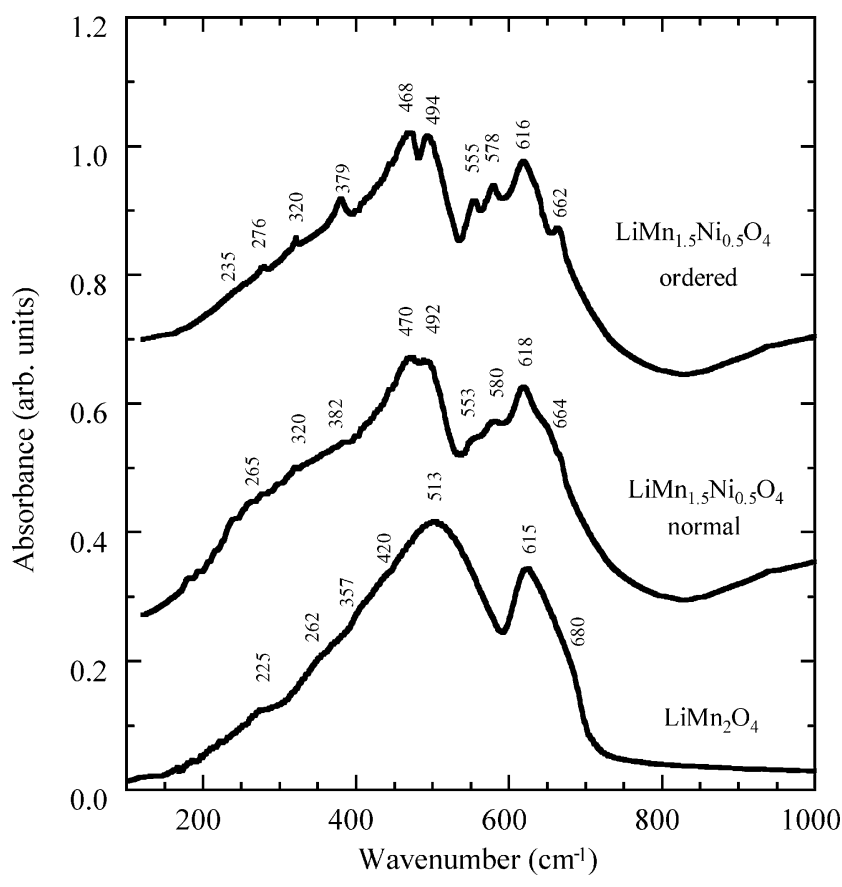

Fig. 7 FTIR absorbance spectra of $\mathrm{LiNi}_{0.5} \mathrm{Mn}_{1.5} \mathrm{O}_{4}$ powders compared with those of undoped $\mathrm{LiMn}_{2} \mathrm{O}_{4}$ normal spinel. Frequencies have been determined by fitting using a mixed Gauss-Lorentz line shape

component $v_{3}$ at $420 \mathrm{~cm}^{-1}$. Four infrared active modes $\left(F_{1 u}\right)$ are allowed in the $O_{h}^{7}$ spectroscopic symmetry [36]. These results displayed in Fig. 7 show that the local structure of $\mathrm{LiNi}_{0.5} \mathrm{Mn}_{1.5} \mathrm{O}_{4}$ is strongly affected by the presence of $\mathrm{Ni}^{2+}$ ions. The FTIR spectrum of the sample grown by glycine-assisted method presents nine wellresolved modes as predicted by the symmetry lowering $O_{h}^{7} \rightarrow O^{7}$. An increase in the number of infrared-active modes confirms the previous RS data.

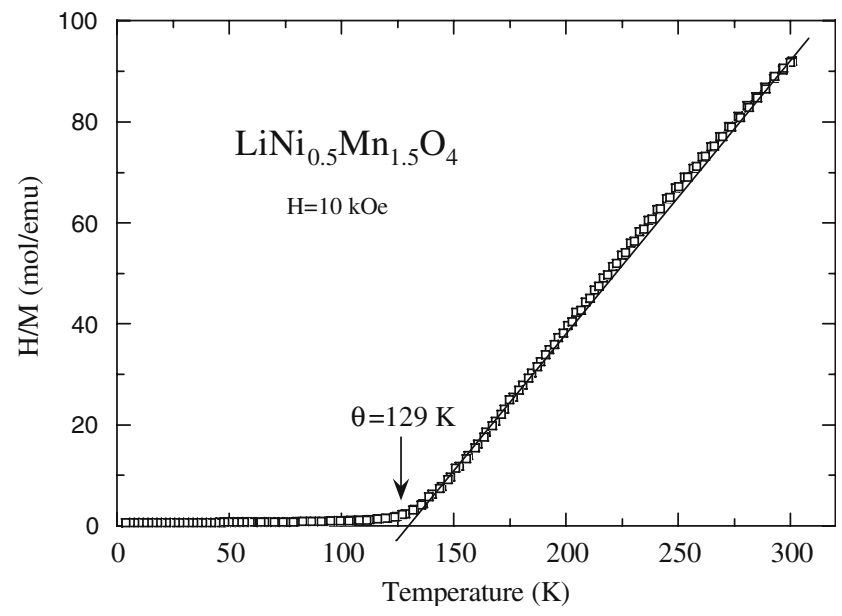

Fig. 8 Temperature dependence of the reciprocal molar magnetization normalized by magnetic fields $(H / M)$ under an applied field $H=10 \mathrm{kOe}$ for $\mathrm{LiNi}_{0.5} \mathrm{Mn}_{1.5} \mathrm{O}_{4}$ spinel grown by wet-chemical route. A ferromagnetic ordering is clearly shown at the Curie temperature $\theta=129 \mathrm{~K}$ for Ni-doped spinel
Magnetic studies

Figure 8 shows the temperature dependence of the reciprocal molar magnetization normalized by magnetic fields $(H / M)$ under an applied field $H=10 \mathrm{kOe}$ for the $\mathrm{LiNi}_{0.5} \mathrm{Mn}_{1.5} \mathrm{O}_{4}$ spinel grown by wet-chemical route. A ferromagnetic ordering is clearly shown at the Curie temperature $\theta=129 \mathrm{~K}$ for Ni-doped spinel. The magnetization was measured at 10 kOe gradually at lower temperatures on field cooling and measurements on heating after zero-field cooling.

Figure 9 displays the field dependence of the magnetization for the $\mathrm{LiNi}_{0.5} \mathrm{Mn}_{1.5} \mathrm{O}_{4}$ sample at different fixed temperatures. Below $150 \mathrm{~K}$, nonlinearity is clearly observed, suggesting the presence of a strong ferromagnetic contribution. At low temperatures, a typical magnetization curve shows the rapid increase with the magnetic field; the magnetic saturation is obtained at a relatively small field. Several authors have reported such a magnetic behavior. Blasse [38] has shown the ferromagnetic spin alignment below $130 \mathrm{~K}$ in $\mathrm{LiNi}_{0.5} \mathrm{Mn}_{1.5} \mathrm{O}_{4}$. Strobel et al. [5] found a large increase in the magnetic susceptibility at low temperature, starting at ca. $120 \mathrm{~K}$ on cooling. These features were attributed to the formation of clusters resulting from a strong magnetic frustration in the structure. Recent results by Nakamura et al. [39] have shown that the asymptotic Curie temperature moved in the positive direction and changed its sign from negative to positive around $y=0.2$ in $\mathrm{LiNi}_{y} \mathrm{Mn}_{2-y} \mathrm{O}_{4}$ spinels. For $\mathrm{LiNi}_{0.5} \mathrm{Mn}_{1.5} \mathrm{O}_{4}$, the ferromagnetism is reported with a saturation magnetization of $105 \mathrm{emu} / \mathrm{g}$ at $5 \mathrm{~K}$.

Due to a large ferromagnetic component, the magnetization curves, $M(H)$, are not linear functions of the applied

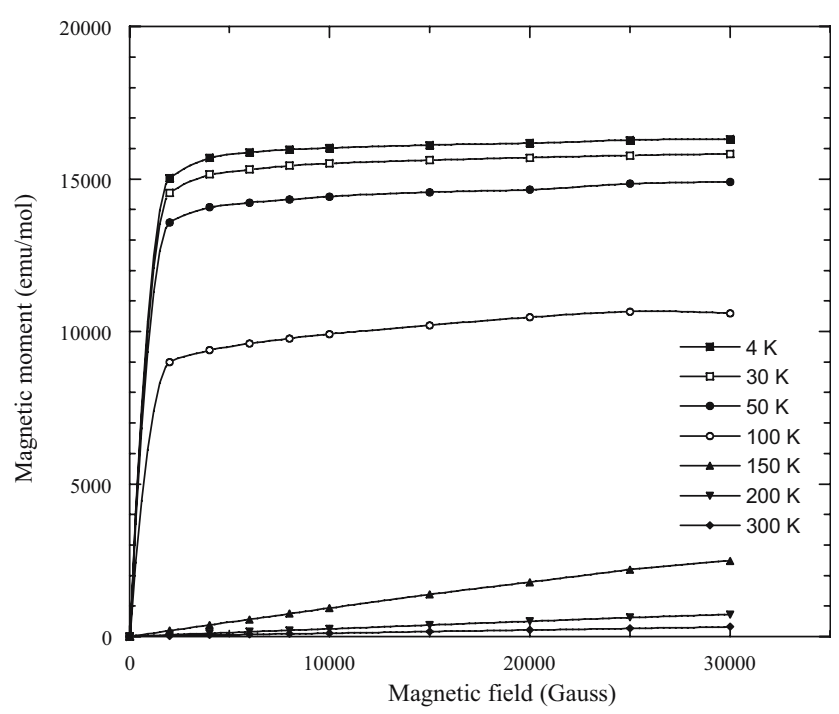

Fig. 9 Magnetization curves of the $\mathrm{LiNi}_{0.5} \mathrm{Mn}_{1.5} \mathrm{O}_{4}$ spinel as a function of the magnetic field $H$ for different fixed temperatures. The sample was zero-field cooled from room temperature to a desired temperature and field was applied stepwise up to $30 \mathrm{kOe}$. The symbols are experimental data. The solid lines are guides for the eyes 


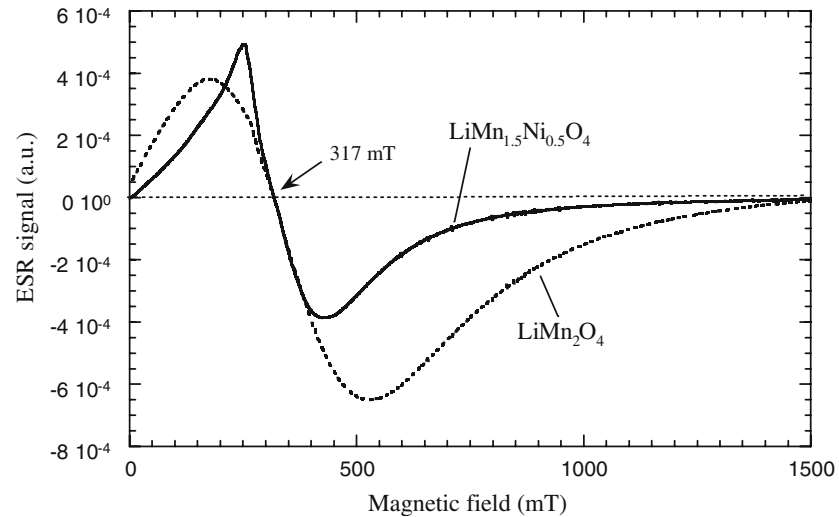

Fig. 10 ESR spectra of $\mathrm{LiMn}_{2} \mathrm{O}_{4}$ and $\mathrm{LiNi}_{0.5} \mathrm{Mn}_{1.5} \mathrm{O}_{4}$ spinels at room temperature. The position of the center of the signal $\left(H_{0}=317 \mathrm{mT}\right)$ is close to the value expected for uncorrelated spins with the gyromagnetic factor $g=2.0$

magnetic field, as shown in Fig. 9. The first consequence is an ambiguity in what is called magnetic susceptibility, $\chi_{\mathrm{m}}$, because $M / H$ is distinct from $d M / d H$. Let us consider two options for the ferromagnetic behavior of $\mathrm{LiNi}_{0.5} \mathrm{Mn}_{1.5} \mathrm{O}_{4}$. First, the material should be considered as a ferromagnet itself, i.e., intrinsic ferromagnetism, due to the couplings $\mathrm{Mn}^{4+}-\mathrm{O}^{2-}-\mathrm{Mn}^{4+}$ and $\mathrm{Ni}^{2+}-\mathrm{O}^{2-}-\mathrm{Ni}^{2+}$. Secondly, ferromagnetic particles could be included in the spinel framework; such impurities $\left(\mathrm{Mn}_{3} \mathrm{O}_{4}\right)$ in small concentrations that cannot be detected by XRD. In this case, one has an extrinsic ferromagnetism. If such particles are present in $\mathrm{LiNi}_{0.5} \mathrm{Mn}_{1.5} \mathrm{O}_{4}$, the ferromagnetism originates from these "clusters." Ferrimagnetic impurities such as $\mathrm{NiO}$ or $\mathrm{Li}_{z} \mathrm{Ni}_{1-z} \mathrm{O}$ are excluded because they possess very high Curie temperatures, e.g., $T c=2,000 \mathrm{~K}$ for $\mathrm{NiO}$ [38]. In this case, the Curie-Weiss law is valid only at $T \gg|\theta|$. This condition can only be fulfilled above room temperature for $\mathrm{LiNi}_{0.5} \mathrm{Mn}_{1.5} \mathrm{O}_{4}$, which precludes a quantitative analysis of the $H / M$ curve. The Curie temperature is determined by experiments (see Fig. 8). At the lowest temperature $T=4 \mathrm{~K}$, the magnetization saturates, so that

$M_{(T=4 K)}=N n \mu_{e f f}(0)$,

where $n$ is the number of magnetic ions of effective moment $p_{\text {eff }} \mu_{B}$. The magnetic moment is equal to $3.02 \mu_{B}$, corresponding to a specific magnetization $88 \mathrm{emu} / \mathrm{g}$ for $\mathrm{LiNi}_{0.5} \mathrm{Mn}_{1.5} \mathrm{O}_{4}$. This value is consistent with the data reported by Nakamura et al. [39].

Figure 10 shows the ESR spectra of $\mathrm{LiMn}_{2} \mathrm{O}_{4}$ and $\mathrm{LiNi}_{0.5} \mathrm{Mn}_{1.5} \mathrm{O}_{4}$ spinels measured at room temperature. The ESR spectrum of $\mathrm{LiMn}_{2} \mathrm{O}_{4}$ consists of a very broad signal (peak to peak width $\Delta H_{\mathrm{pp}} \approx 350 \mathrm{mT}$ ) centered at about $H_{0}=317 \mathrm{mT}$. The position of the center of the signal is close to the value expected for uncorrelated spins with the gyromagnetic factor $g=2.0$. The ESR signal is currently attributed to the contribution of $\mathrm{Mn}^{4+}$ entities [40]. The $\mathrm{Mn}^{4+}-\mathrm{Mn}^{4+}$ dipolar interactions, as well as the $\mathrm{Mn}^{4+}-\mathrm{Mn}^{3+}$ ones, contribute to the broadening of the signal. The ESR spectrum of $\mathrm{LiNi}_{0.5} \mathrm{Mn}_{1.5} \mathrm{O}_{4}$ shows a much narrower signal $\left(\Delta H_{\mathrm{pp}} \approx 170 \mathrm{mT}\right)$ centered at $g=2.0$. The band has a complex shape with two components. The signal is attributed to $\mathrm{Mn}^{4+}$ ions, which are the only paramagnetic entities in this compound.

\section{Electrochemical studies}

The electrochemical properties of $\mathrm{LiNi}_{0.5} \mathrm{Mn}_{1.5} \mathrm{O}_{4}$ spinels have been widely reported [13-25]. Also, in this section, we briefly present the electrochemical data of our samples prepared by wet-chemical methods. The first chargedischarge profiles of the spinel $\mathrm{Li} / / \mathrm{LiNi}_{0.5} \mathrm{Mn}_{1.5} \mathrm{O}_{4}$ cells in the voltage range 3.5-4.9 $\mathrm{V} \mathrm{vs} \mathrm{Li}^{0} / \mathrm{Li}^{+}$have been recorded for normal $A\left[B_{2}\right] \mathrm{O}_{4}$ spinel lattice (Fig. 11a) and for ordered 1:3 spinel framework (Fig. 11b). Our data are consistent with those of prior results in terms of their high-voltage characteristics [41]. As can be seen in Fig. 11, the $\mathrm{LiNi}_{0.5} \mathrm{Mn}_{1.5} \mathrm{O}_{4}$ samples reveal an operating voltage higher
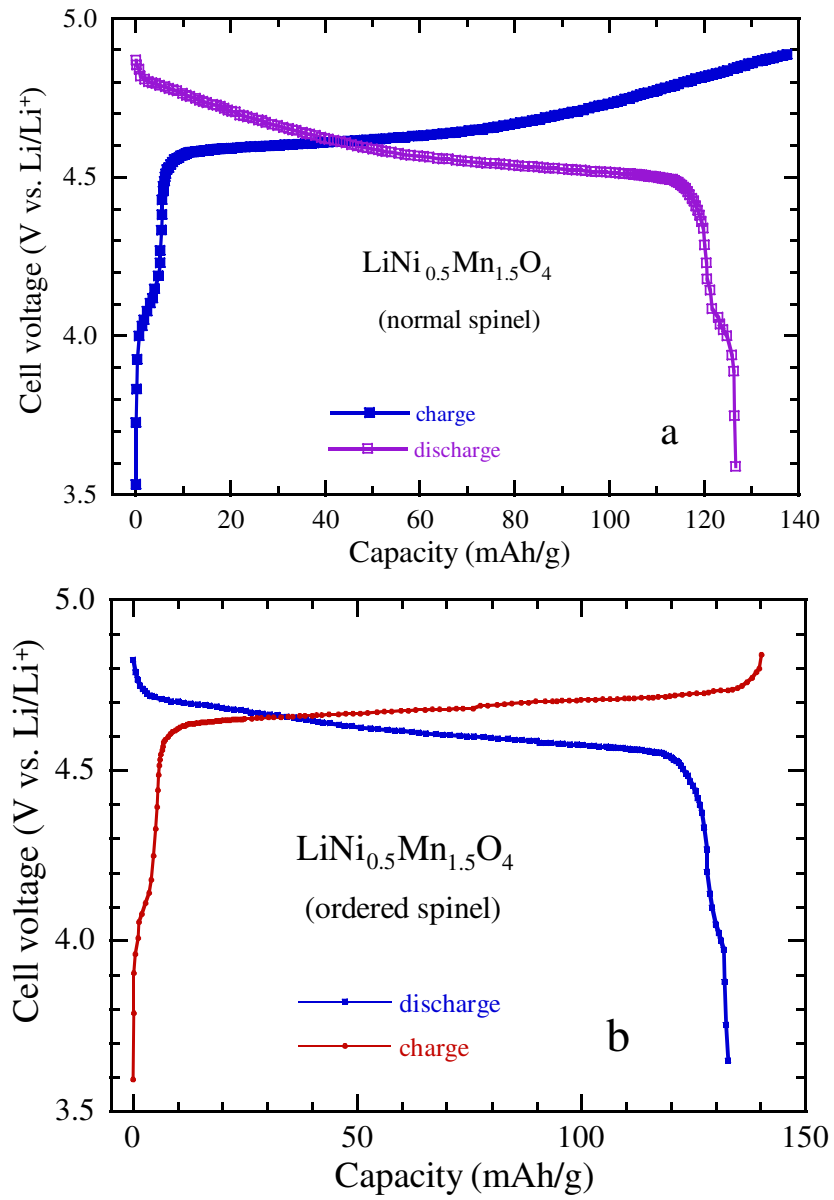

Fig. 11 The first charge-discharge profile of the spinel $\mathrm{Li} / /$ $\mathrm{LiNi}_{0.5} \mathrm{Mn}_{1.5} \mathrm{O}_{4}$ cells in the voltage range 3.5 to $4.9 \mathrm{~V}$ vs $\mathrm{Li}^{0} / \mathrm{Li}^{+}$. a normal $A\left[B_{2}\right] \mathrm{O}_{4}$ spinel lattice and b ordered 1:3 spinel framework 


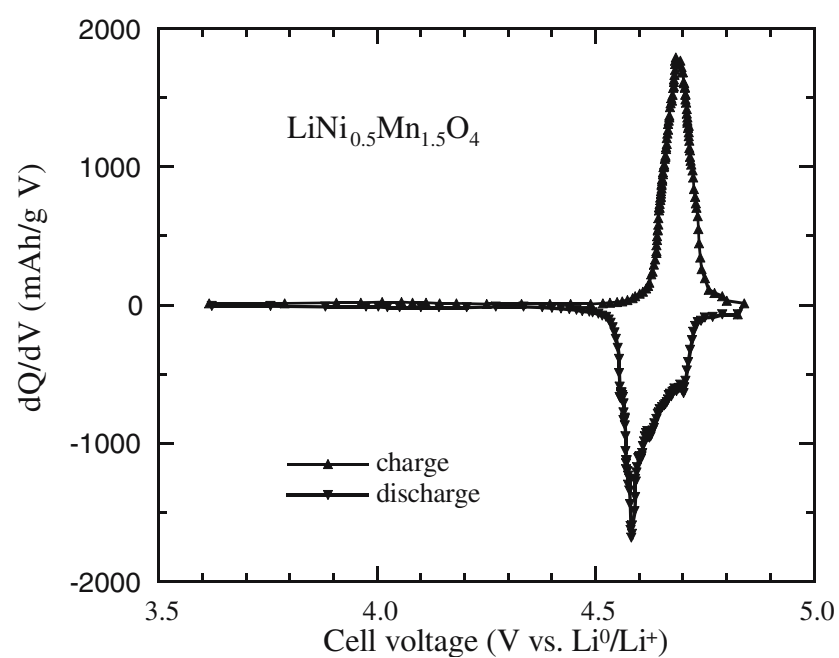

Fig. 12 Plot of the incremental derivative capacity $(-\partial Q / \partial V)$ for the $\mathrm{Li} / / \mathrm{LiNi}_{0.5} \mathrm{Mn}_{1.5} \mathrm{O}_{4}$ cell as a function of the cell voltage vs $\mathrm{Li}^{0} / \mathrm{Li}^{+}$ for the first charge-discharge process

than 4.5 V. They reveal an obvious two-step lithium intercalation/deintercalation behavior. A small plateau appears at ca. $4.0 \mathrm{~V}$, related to the redox couple $\mathrm{Mn}^{3+}$ / $\mathrm{Mn}^{4+}$. The appearance of the voltage plateau at $4.7 \mathrm{~V}$ has been attributed to the oxidation of $\mathrm{Ni}^{2+}$ to $\mathrm{Ni}^{4+}$ [4]. The normal-spinel phase shows predominantly one-step reaction at $4.65 \mathrm{~V}$, while the voltage profile of the orderedspinel structure transforms from a sloping curve to a flat curve at $4.72 \mathrm{~V}$. In the voltage range $3.5-4.9 \mathrm{~V}$, the $\mathrm{Li} / /$ $\mathrm{LiNi}_{0.5} \mathrm{Mn}_{1.5} \mathrm{O}_{4}$ delivers a capacity $133 \mathrm{mAh} / \mathrm{g}$ during the first discharge.

Figure 12 displays the plot of the incremental derivative capacity $(-\partial Q / \partial V)$ for the $\mathrm{Li} / / \mathrm{LiNi}_{0.5} \mathrm{Mn}_{1.5} \mathrm{O}_{4}$ cell as a function of the cell voltage $\mathrm{vs} \mathrm{Li}^{0} / \mathrm{Li}^{+}$for the first chargedischarge process. The two main regions of electrochemical activity appear at 4.0 and $4.7 \mathrm{~V}$. These results illustrate

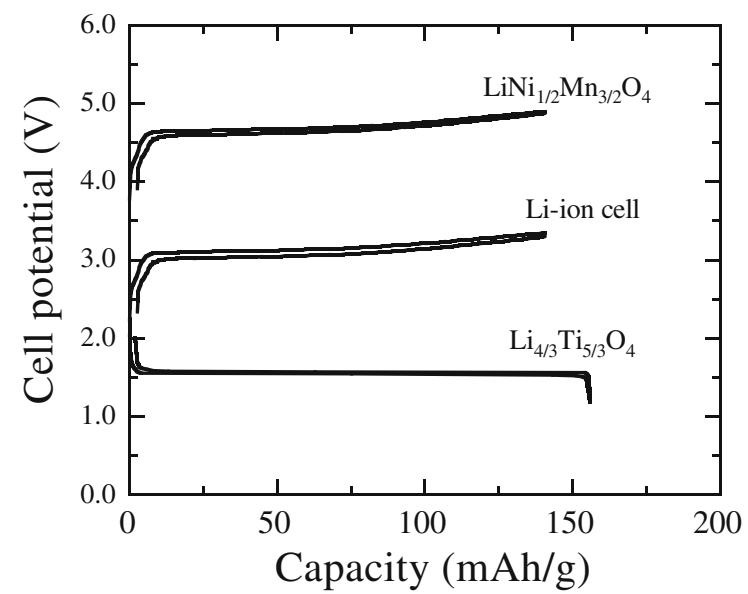

Fig. 13 Voltage profile of the first charge-discharge of a Li-ion cell containing $\mathrm{LiNi}_{0.5} \mathrm{Mn}_{1.5} \mathrm{O}_{4}$ spinel as positive electrode and $\mathrm{Li}_{1.33} \mathrm{Ti}_{1.66} \mathrm{O}_{4}$ spinel as negative electrode well the reversibility of this material upon deintercalation and intercalation of lithium ions.

The high-voltage operation of $\mathrm{LiNi}_{0.5} \mathrm{Mn}_{1.5} \mathrm{O}_{4}$ spinels allows the use of an oxide-based material as negative electrode in Li-ion batteries. Among the spinel frameworks, $\mathrm{LiCrTiO}_{4}$ [42] and $\mathrm{Li}_{1.33} \mathrm{Ti}_{1.66} \mathrm{O}_{4}$ [43] are interesting candidates. A Li-ion cell containing $\mathrm{LiNi}_{0.5} \mathrm{Mn}_{1.5} \mathrm{O}_{4}$ spinel as positive electrode and $\mathrm{Li}_{1.33} \mathrm{Ti}_{1.66} \mathrm{O}_{4}$ spinel as negative electrode has been tested. Figure 13 shows the voltage profile of the first charge-discharge of such a cell. Long life tests are in progress. This battery operates at an average potential $3.15 \mathrm{~V}$ and exhibits a capacity retention $145 \mathrm{mAh} / \mathrm{g}$ at the first charge-discharge cycle.

\section{Conclusion}

In this work, we have developed wet syntheses such as solgel and pyrolysis assisted by carboxylic acid to grow $\mathrm{LiNi}_{0.5} \mathrm{Mn}_{1.5} \mathrm{O}_{4}$ spinel materials. Structural and electrochemical characterizations were made and properties were compared with $\mathrm{LiMn}_{2} \mathrm{O}_{4}$ spinel. The overall picture that emerges from these investigations is as follows.

Depending of the preparation procedure, two varieties of samples were obtained: the normal-spinel structure (via citric acid) and the ordered-spinel structure (via glycine). These structures refined with the $F d 3 m$ and $P 4_{1} 32$ SGs, respectively, show a smaller cubic unit cell than the undoped $\mathrm{LiMn}_{2} \mathrm{O}_{4}$ spinel. The shortening of $\mathrm{M}-\mathrm{O}$ bonds is observed in Raman spectra by a shift of the stretching mode of $\mathrm{MnO}_{6}$ entities. The superstructure of $\mathrm{LiNi}_{0.5} \mathrm{Mn}_{1.5} \mathrm{O}_{4}$ material grown by pyrolysis method is confirmed by local probes, such as Raman and FTIR. Raman measurements reveal that the oxidation state of $\mathrm{Ni}$ was +2 in $\mathrm{LiNi}_{0.5} \mathrm{Mn}_{1.5} \mathrm{O}_{4}$ spinels. Magnetic measurements have evidenced the ferromagnetic ordering below $T_{c}=129 \mathrm{~K}$ in $\mathrm{LiNi}_{0.5} \mathrm{Mn}_{1.5} \mathrm{O}_{4}$.

The replacement of the $3 \mathrm{~d}^{8}-\mathrm{Ni}$ for $\mathrm{Mn}$ in $\mathrm{LiNi}_{0.5} \mathrm{Mn}_{1.5} \mathrm{O}_{4}$ oxides is beneficial for its charge-discharge cycling performance. For a cut-off voltage 3.5-4.9 V, the electrochemical capacity of the $\mathrm{Li} / / \mathrm{LiNi}_{0.5} \mathrm{Mn}_{1.5} \mathrm{O}_{4}$ cell is ca. $133 \mathrm{mAh} / \mathrm{g}$ during the first discharge.

Acknowledgements The authors wish to thank Mrs. F. Soulette for her assistance in the experimental work. Mr. M. Selmane is gratefully acknowledged for support on XRD measurements and Rietveld refinement. The work has partly supported by a grant-in-aid from the Centre National de la Recherche Scientifique-Délégation Générale à la Recherche Scientifique et Technologique collaboration program (project No. SPM13939).

\section{References}

1. Winter M, Besenhard JO, Spahr ME, Novak P (1998) Adv Mater 10:725

2. Wakihara M (2001) Mater Sci Eng R Rep 38:1

3. Gao Y, Myrtle K, Zhang MJ, Reimers JN, Dahn JR (1996) Phys Rev B 54:16670 
4. Zhong Q, Bonakdarpour A, Zhang M, Gao Y, Dahn JR (1997) J Electrochem Soc 144:205

5. Strobel P, Ibarra-Palos A, Anne M, Le Cras F (2000) J Mater Chem 10:429

6. Strobel P, Ibarra-Palos A, Anne M, Poinsignon C, Crisci A (2003) Solid State Sci 5:1009

7. Kanamura K, Hoshikawa W, Umegaki T (2002) J Electrochem Soc 149:A339

8. Alcantara R, Jaraba M, Lavela P, Tirado JL (2002) Electrochim Acta 47:1829

9. Wu X, Kim SB (2002) J Power Sources 109:53

10. Kim J-H, Myung S-T, Sun Y-K (2004) Electrochim Acta 49:220

11. Myung S-T, Komaba S, Kumagai N, Yashiro H, Chung H-T, Cho T-H (2002) Electrochim Acta 47:2543

12. Lee YS, Sun YK, Ota S, Miyashita T, Yoshio M (2002) Electrochem Commun 4:989

13. Ohzuku T, Takeda S, Iwanaga M (1999) J Power Sources 81-82:90

14. Okada M, Lee Y-S, Yoshio M (2000) J Power Sources 90:196

15. Dokko K, Mohamedi M, Anzue N, Itoh T, Uchida I (2002) J Mater Chem 12:3688

16. Ariyoshi K, Iwakoshi Y, Nakayama N, Ohzuku T (2004) J Electrochem Soc 151:A296

17. Hong K-J, Sun Y-K (2002) J Power Sources 109:427

18. Wu HM, Tu JP, Yuan YF, Li Y, Zhao XB, Cao GS (2005) Electrochim Acta 50:4104

19. Park S-H, Sun Y-K (2004) Electrochim Acta 50:429

20. Liu GQ, Wang YJ, Qilu, Li W, Chenhui (2005) Electrochim Acta 50:1965

21. Sun Y-K, Hong K-J, Prakash J, Amine K (2002) Electrochem Commun 4:344

22. Sun Y-K, Yoon CS, Oh I-H (2003) Electrochim Acta 48:503

23. Ooms FGB, Kelder EM, Schoonman J, Wagemaker M, Mulder FM (2002) Solid State Ionics 152-153:143

24. Takahashi K, Saitoh M, Sano M, Fujita M, Kifune K (2004) J Electrochem Soc 151:A173
25. Amine K, Tukamoto H, Yasuda H, Fujita Y (1996) J Electrochem Soc 143:1613

26. Blasse G (1966) J Phys Chem Solids 27:383

27. Gryffroy D, Vaudenberghe RE (1992) J Phys Chem Solids 53:777

28. Julien C, El-Farh L, Rangan S, Massot M (1999) J Sol-Gel Sci Technol 15:63

29. Chitra S, Kalyani P, Mohan T, Gangadharan R, Yebka B, Castro-Garcia S, Massot M, Julien C, Eddrief M (1999) J Electroceram 3:433

30. Julien C, Letranchant C, Lemal M, Ziolkiewicz S, CastroGarcia S (2002) J Mater Sci 37:2367

31. Marquardt DW (1963) J Soc Ind Appl Math 11:431

32. Soppe W, Kleerebezem J, den Hartog HW (1987) J Non-Cryst Solids 93:142

33. Julien C, Ziolkiewicz S, Lemal M, Massot M (2001) J Mater Chem 11:1837

34. Kawai H, Tabuchi M, Nagata M, West (1998) J Mater Chem $8: 1273$

35. Klug HP, Alexander LE (1974) X-Ray diffraction procedures for polycrystalline and amorphous materials. Wiley, New York

36. Allen GC, Paul M (1995) Appl Spectrosc 49:451

37. Cordoba-Torresi SI, Hugot-Le Goff A, Joiret S (1991) J Electrochem Soc 138:1554

38. Blasse G (1966) J Phys Chem Solids 27:383

39. Nakamura T, Yamada Y, Tabuchi M (2005) J Appl Phys 98:93905

40. Capsoni D, Bini M, Chiodelli G, Massarotti V, Mozzatti MC, Anzoni C (2003) Solid State Commun 125:179

41. Julien CM, Massot M (2004) In: Extended abstracts of the 5th France-Japan joint seminar on lithium batteries. Batz-sur-Mer, p 11 (September 26-28)

42. Ooms FGB, Kelder EM, Schoonman J (2001) IEE Batter Lett 2:B59

43. Julien CM, Zaghib K (2004) Electrochim Acta 50:411 